\title{
Stem quality assessment in European National Forest Inventories: an opportunity for harmonised reporting?
}

\author{
Michal Bosela $^{1,2}$ • John Redmond ${ }^{3} \cdot$ Miloš Kučera $^{4} \cdot$ Gheorghe Marin $^{5} \cdot$ Radim Adolt $^{4}$ • \\ Thomas Gschwantner ${ }^{6}$ - Rudolf Petráš ${ }^{1}$ - Kari Korhonen ${ }^{7} \cdot$ Andrius Kuliešis $^{8}$. \\ Gintaras Kulbokas $^{8}$ • Christoph Fischer ${ }^{9}$ - Adrian Lanz ${ }^{9}$
}

Received: 16 February 2015 / Accepted: 16 July 2015 / Published online: 31 July 2015

(C) INRA and Springer-Verlag France 2015

\begin{abstract}
- Key message The potential of European National Forest Inventories to harmonise stem quality estimation in European forests was identified despite considerable differences in existing national approaches.

- Context Knowledge on stem quality and assortments structure in European forests is highly important for policy makers and the timber industry and also for carbon life cycle analysis due to the fact that different timber products have different end use and thus store carbon for different time periods.
\end{abstract}

\section{Handling Editor: Jean-Michel Leban}

Contribution of the co-authors MB, JR and MK designed the study, performed the questionnaire study and wrote the manuscript;

GM contributed in designing the questionnaire and revised the manuscript;

GM, KK, AK, GK prepared a description of the timber quality assessment in their NFIs and revised the manuscript;

$\mathrm{RA}, \mathrm{TG}, \mathrm{CF}$ and $\mathrm{AL}$ reviewed literature and revised the manuscript.

Electronic supplementary material The online version of this article (doi:10.1007/s13595-015-0503-8) contains supplementary material, which is available to authorized users.

Michal Bosela

bosela@nlcsk.org

1 National Forest Centre, T.G. Masaryka 22, 96092

Zvolen, Slovakia

2 Faculty of Forestry and Wood Sciences, Czech University of Life Sciences Prague, Praha, Czech Republic

3 Department of Agriculture, Food and the Marine, Johnstown Castle Estate, Wexford, Ireland
- Aims The study aim was to evaluate the potential of European National Forest Inventories (NFI) to objectively report on the stem quality in European forests in a harmonised manner.

- Methods A comprehensive questionnaire was conducted as the first important step to evaluate the current status of stem quality assessment and assess the existing level of harmonisation.

- Results Direct stem quality assessment or classification is used in 19 out of 28 European NFIs. Only eight countries provide timber assortment estimates from their NFIs. In addition, different sampling strategies for stem quality assessment are used among NFIs. Tree parameters relevant for stem quality assessment on standing trees were identified for the purpose of harmonisation. Several methods towards harmonisation between European NFIs for the purpose of reporting on stem quality of European forests were suggested. - Conclusion Current European NFIs are not capable of reporting the stem quality of European forests in a harmonised manner at this stage and considerable efforts will need to be taken before the harmonised stem quality estimation can be

Forest Research and Management Institute, Bucharest, Romania

6 Federal Research and Training Centre for Forests, Natural Hazards and Landscape (BFW), Wien, Austria

7 Finnish Forest Research Institute, Natural Resources Institute Finland (Luke), Joensuu, Finland

8 Aleksandras Stulginskis university, Kaunas reg., Academia, Kèdainiai, Lithuania

9 Swiss Federal Research Institute WSL, Birmensdorf, Switzerland 
prepared. However, the inquiry also revealed that there is a potential to develop the harmonised estimations in future.

Keywords Timber grading $\cdot$ Timber assortments $\cdot$ Carbon storage $\cdot$ Sample-based inventory $\cdot$ Reporting $\cdot$ Harmonisation

\section{Introduction}

The question of wood availability in Europe on a sustainable basis is highly relevant to define global change strategies and targets for biomass energy as adopted at national and European level (European Parliament and Council of the European Union 2009) and to support the proposal of an increased use of wood as a post-Kyoto decision (COST 2015). Information on the quantity of timber on its own is not sufficient, as the quality and assortment structure of trees play a crucial role in determining the end use. Just knowing the quantity and availability of wood is not enough for the timber market and policy decision making. The economic value of forests is crucial also to individual forest owners and forest companies, enabling them to effectively plan forest management operations (Kankare et al. 2014a, b). Measuring the volume of a tree does not tell us enough about the available assortments and products. The size and quality of the tree stem determines its end use and thus the life-span of the forest product which is of importance in carbon life cycle analysis (Eriksson et al. 2007). For example, the carbon content of firewood returns to the atmosphere in a short time after cutting whilst timber used for furniture stores carbon for very long time. The second commitment period of the Kyoto Protocol involves new provisions for the treatment of harvested wood products (HWP). Accordingly, parties shall account for the change in the harvested wood products pool if transparent and verifiable information about paper, wood panels and sawn wood is available (IPCC 2014).

However, assessing stem quality or assortment structure of forests is not an easy task. Usually, timber quality is assessed (or measured) after harvesting when the logs are sorted, as it is far easier to quantify the parameters that are required when classifying into the assortments. However, knowing the timber quality of standing trees is important where wood is sold "on the stump." It also informs the wood processing industry of the type of wood that will be available, which enables appropriate strategic investment, capacity building and marketing decisions to be evaluated. The information also supports the sustainable management of forests as the best use can be made of the wood resources available. The assessment of timber quality helps to differentiate the wood resource prior to processing (Rais et al. 2014). Information on the quantity and quality of the potential supply of raw material from current forest resources and those expected in the future is important for the wood industry when strategic decisions are made
(Nuutinen et al. 2009). Methods to estimate the available assortments from standing timber are needed to determine the quantity and quality of the timber resource in many areas. This information will identify the optimum location for processing plants and how much timber is economically operable to existing industries. Measurement of timber quality characteristics can enhance (or at least maintain) the value for the seller, whilst minimising risk to the purchaser. Accurate timber resource information will assist in the development of forest management, timber production, manufacturing and marketing techniques to meet demands for forest products.

National Forest Inventories (NFI) are well placed to provide the timber industry, the pulp and paper industry, the energy sector and policymakers with information on the timber quality in an individual country. However, establishing within the NFIs at European level a harmonised assessment of timber quality of the main European tree species remains challenging. Furthermore, before any harmonisation of stem quality assessment is made there is a need to harmonise single tree- and timber qualityrelated parameters. This has been the subject of last two COST Actions, E43 (COST 2010) (Vidal et al. 2008; Gschwantner et al. 2009; McRoberts et al. 2009, 2010; Ståhl et al. 2012; Tomppo and Schadauer 2012; Tomter et al. 2012) and FP1001 (COST 2015). Therefore, this study is primarily focused on stem quality-related parameters assessment in European NFIs.

As there is no scientific literature, this study is the first to attempt to answer the question whether European NFIs have the potential to provide European policy makers and the timber industry with harmonised and relevant information on the quality structure of wood resources in European forests. The aim of the paper is thus to examine the status of stem quality and assortments assessment in NFIs in Europe and outline opportunities for harmonisation. In addition, there is also different and not comprehensively harmonised terminology using the terms such as "timber" or "wood quality" (MacDonald and Hubert 2002; van Leeuwen et al. 2011; Rais et al. 2014), "stem" or "wood properties" (Nuutinen et al. 2009), "stem quality" (Schneider et al. 2008). Therefore, the following strategy was applied in the study: (a) overview of existing methods for stem quality and assortments assessment in NFIs using questionnaires and country reports; (b) overview of assessed stem quality parameters in NFIs using questionnaires and country reports; (c) overview of national and international standards of stem quality classification; (d) to propose harmonised definitions; and (e) discuss the potential to harmonise stem quality estimation in European NFIs.

\section{Materials and methods}

\subsection{Study area}

In this study, 28 countries were involved, representing the majority of Europe's land base (Fig. 1). These countries 
together have a forest area of more than 169 million ha, growing stock of more than 23 billion $\mathrm{m}^{3}$, and annual removals of wood products (roundwood and fuelwood) amounting to more than $450 \mathrm{mil} \mathrm{m}^{3}$ (FAO 2010). All these countries participated on the COST Action FP1001 (COST 2015), which facilitated effective communication.

\subsection{Questionnaires and country reports}

For this study, a questionnaire was prepared and individual countries were asked to provide answers. In addition, the countries involved in the questionnaire were also asked to provide a comprehensive country report describing wood resource availability in their countries. The country reports complemented the questionnaires by providing additional information which facilitated a better understanding of the answers to the questionnaire.

The questionnaire focussed on obtaining information about the use of stem quality assessment or assortment quantification in the NFIs. The questions were split into three parts in order to distinguish between field assessment of tree parameters related to stem quality classification, direct stem quality classification in the field and timber assortments generation/ assessment (Online Resource 1).

\subsection{Comparison of stem quality assessment and assortment generation}

Country examples are used to show the variability in stem quality assessment and assortment estimation over the Europe, including: Czech Republic, Slovakia, Finland, Romania and Lithuania. These countries were selected because their NFIs include a stem quality assessment and, in addition, they estimate assortments of the standing trees.

\subsection{Data processing}

Firstly, definitions were prepared for the basic characteristics related to the subject matter. For this purpose, national and international standards as well as literature research were consulted.

In the next step, a set of questions, which were considered to be most important in terms of stem quality and assortments quantification, was selected and results were prepared in the form of summary tables and figures.

The analysis focused on the identification of the most important parameters used in assessment of stem quality in NFI's (e.g. damage to the stem, tree fork, number and size of living or dead knots, etc.) and also additional parameters needed for assortment quantification (diameter at breast height (dbh), height, species, etc.). A list of the parameters, with an indication of priority in terms of stem quality and assortment assessment was prepared.

\section{Results}

\subsection{European standards}

At European level a number of standards have been developed in relation to the quality of round timber. These standards represent a model specification and are seen as a technical solution against which a market can trade.

These standards have been developed by the European Committee for Standardization (CEN). CEN is a major provider of European Standards and technical specifications. It is the only recognised European organisation according to Directive 98/34/EC for the planning, drafting and adoption of European Standards in relation to roundwood quality. This Directive imposes an obligation upon each member state to inform the Commission, and every other member state, of technical regulations and technical standards in draft, before they are adopted in national law.

CEN's national members are the National Standards Bodies of the 28 European Union countries, the former Yugoslav Republic of Macedonia, and Turkey plus three countries of the European Free Trade Association (Iceland, Norway and Switzerland). There is one member per country. It is the responsibility of the CEN National Members to implement European Standards as national standards, which is unique in the world. The National Standards Bodies distribute and sell the implemented European Standard and have to withdraw any conflicting national standards.

\subsection{Reference definitions}

Only characteristics directly related to stem and timber quality are defined in this paper. The definitions were drafted during the meetings of Working Group 1 of Cost Action FP1001 (COST 2015). They rely on the definitions of tree parts such as bole and stem available from Gschwantner et al. (2009) and Tomppo et al. (2010).

Here, we distinguish between timber (syn. wood) quality and stem quality for the purpose of assessment in NFI. Timber quality cannot be assessed on standing trees as it also includes physical properties which are not visible on the standing tree (MacDonald and Hubert 2002). On the other hand, stem quality includes only visible properties and signs on standing trees which are possible to be assessed during NFI. The both are, however, closely related as stem quality assessment is used to infer on timber quality and possibly end use product.

\subsubsection{Timber quality (syn. wood quality)}

The term, although widely used, is not that easy to define in a general way, as the definition can vary between different 
Fig. 1 European countries which responded to the questionnaire within the COST Action FP1001 (grey colour)

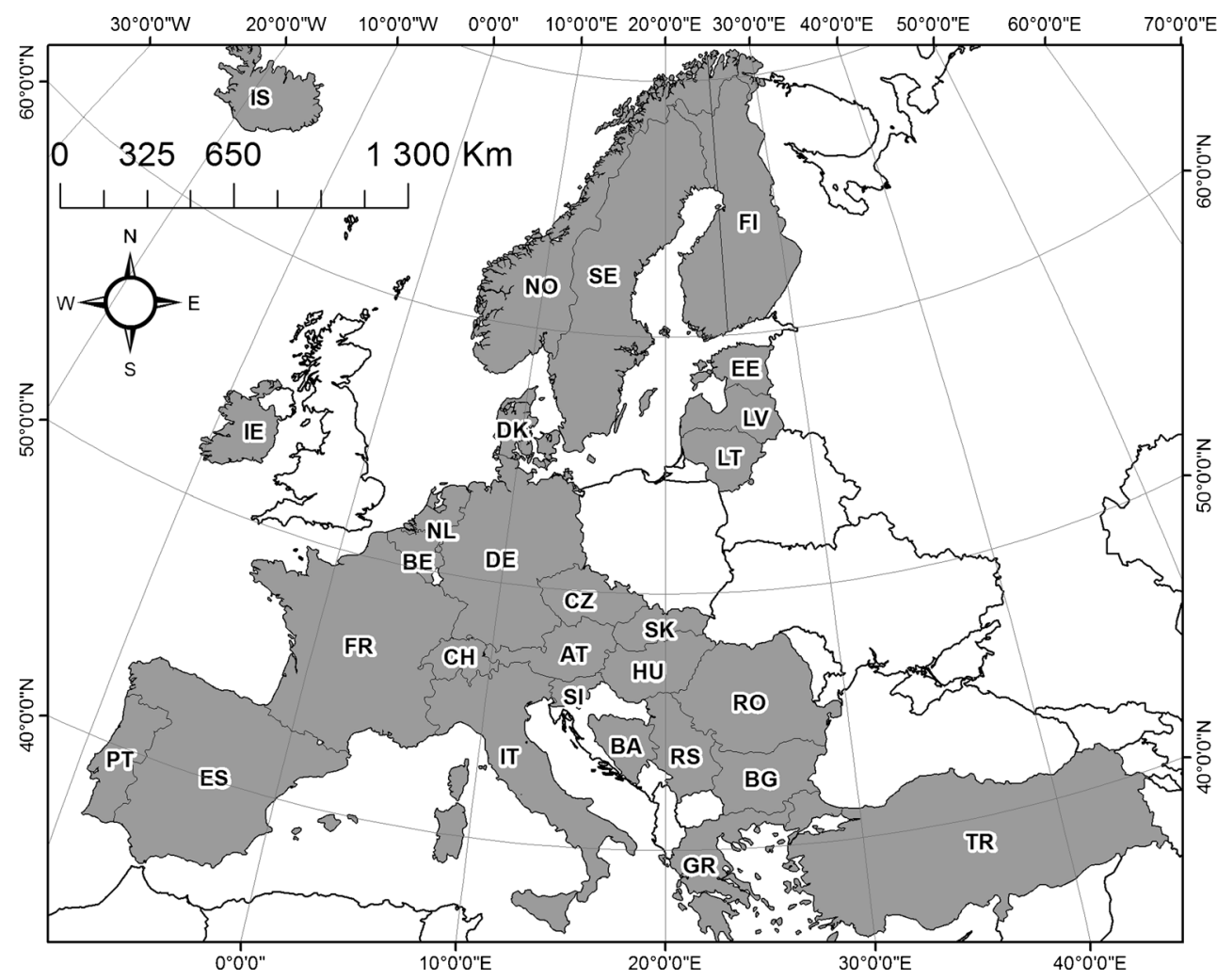

forestry sectors and timber industry (Mitchell 1961; Kliger et al. 1994) and in isolation the term has only little meaning (Chauhan et al. 2006). The first broadly used definition was provided by Mitchell (1961): "wood quality is the resultant of physical and chemical characteristics possessed by a tree or a part of a tree that enable it to meet the property requirements for different end products." Latter, Zhang (1997) provided a useful and a much broader definition of timber quality: "all the wood characteristics and properties that affect the value recovery chain and the serviceability of end products." With this definition, he went further and stressed that wood quality definition must include such characteristics that influence the manufacturing process and product value at every step of the chain (e.g. harvesting, transportation, storage, bucking, debarking, lumber drying, etc.). Wood quality attributes thus include stem diameter, stem form and defects, stem taper, tree age, bark, stem decay, knottiness, reaction wood, growth stresses, grain deviation, juvenile wood, heartwood/sapwood ratio, anatomical characteristics, chemical composition, ring characteristics, moisture content, wood density, dimensional stability, mechanical properties, durability, wood permeability, aesthetic characteristics, machinability, fire resistance, finishing, engineering properties, other (e.g. acoustic, thermal, electrical and other properties).

However, most of the timber properties are difficult (some even impossible) to assess on standing trees, therefore stem quality should be assessed instead.

\subsubsection{Stem quality}

Stem quality is the visual quality of standing tree assessed in the field. Physical properties such as straightness, knots, visible forms of decay, rotting and other parameters that affect the utilisation of logs can be used for visual assessment of stem quality.

However, when assessing stem quality of standing trees one often needs to rely only on visible signs or symptoms of some parameters that are important (e.g. stem cavity might suggest rotting). Many parameters can be directly measured (dbh, height, number and size of knots or branches) and other parameters can be only assessed on a non numerical scale (occurrence of some type of damage and assessing its intensity). But it is often inefficient to measure all required parameters directly in the field, thus visual estimation and classification into categories that combine the most important parameters can be applied instead.

\subsubsection{Assessment of the quality of standing trees in the field}

To overcome potential ambiguity, it is necessary to highlight the differences in timber quality and properties assessment between standing trees and trees cut down. For standing trees, there are usually several parameters related to the timber quality that can be assessed or measured in the field (dbh, height, height of crown base, etc.), some can be derived from 
measured parameters (e.g. tapering derived from dbh and tree height measurement) and some can only be inferred on (e.g. rotting). For standing trees it is often difficult or economically inefficient to assess the available assortments for the whole stem, rather it is more common to assess only the lower part of a stem (e.g. fixed length of 5 or $7 \mathrm{~m}$, or $1 / 3$ of the length). The quality classes derived for a stem can also be estimated using assortment models, which rely on the data collected in the field as input variables. However, such models are not available for all countries and in that case a stem must be graded directly in the field.

\subsubsection{Assortments}

Potential end product determined by market need. They are defined combining timber quality parameters and tree dimensions (e.g. length and diameter).

This relates to the dimensions of the products into which a stem can be cut. Assortments represent the size, quality and quantity available for potential manufacture of specific end products (e.g. lumber, veneer, shingles and chips). There are thresholds for diameter (at one or both ends of a $\log$ ) and length used in defining the timber assortment. However, there are often national thresholds (diameter, length) that define the timber assortments, but there also exist European standards (e.g. EN 1927-1 for spruces and firs).

\subsection{Stem quality assessment in European NFIs}

As many as 28 countries responded in the questionnaire that they record stem parameters in the field which could be further used for stem quality assessment (Table 1). However, only 18 countries directly classify or assess stem quality in their NFIs (Fig. 2) and as few as 8 countries use quality classes that are assessed in the field for subsequent quantification of timber assortments (Fig. 3).

There are even different strategies for sampling trees between NFIs. In addition, there were some other specifications of sample trees selection in countries. Concerning the sampling strategy, 11 countries measure and record stem quality parameters for all trees registered in the sample plots, whilst 15 countries use only a sub-sample of trees (Table 2). The Austrian NFI assesses stem quality on sample trees with a dbh over $20.4 \mathrm{~cm}$, whilst Bosnia and Herzegovina uses a minimum dbh of $5 \mathrm{~cm}$. Czech Republic assesses quality parameters for all trees with dbh over $7 \mathrm{~cm}$ on the plot with a radius of $5 \mathrm{~m}$ and trees with dbh over $27 \mathrm{~cm}$ on the plot with a radius of $12.62 \mathrm{~m}$ (these thresholds are at the same time the registration thresholds for tree recording). The same strategy is applied in Slovakian NFI, but the thresholds are different (trees with dbh in the range of 7-12 $\mathrm{cm}$ are sampled in the plot with the radius of $3 \mathrm{~m}$ whilst trees with dbh over
$12 \mathrm{~cm}$ are recorded on the plot with a radius of $12.62 \mathrm{~m})$. The Danish NFI applies random selection proportional to size, whilst Estonia generally selects every third tree for this purpose.

As many as eighteen countries distributed over the Europe apply some kind of stem quality classification (Fig. 2). There are countries from southern, central and northern parts of Europe. However, a different number of classes are used among the countries. The largest number of classes is used in Finland, whilst only two quality classes are used in Lithuania. Moreover, differences are also in the classes definitions (see Online Resource 3 for detail comparison). A special case is the Swedish NFI. They do not provide estimates for timber quality or assortments directly from NFI data, but these data are used as an input to the RegWise forecasting system, in which projections for distributions of assortments are made for timber and pulp wood (Wikström et al. 2011). The question of stem quality and assortment assessment in their NFI has been discussed since the first NFI (1923), but no system has satisfied enough.

Far fewer NFIs use some kind of assortment generation and quantification (Fig. 3). Despite the small number of countries, they are distributed across the whole Europe.

Concerning land use type, knowledge on stem quality or assortment structure is mostly important for the forest domain. However, as the importance of the timber resources located outside the forest domain has been increasing, the NFIs were also asked to specify on which land use types they collect data for stem quality assessment. Less than $40 \%$ of NFIs record parameters for other wooded land, and very few countries have some information for other domains such as trees outside forest, other land with tree cover (Table 3).

Finally, a list of tree parameters was prepared which may be useful for stem quality or assortment assessment (Table 4). It presents the order of parameters from the most to least frequently recorded during the field data collection. It is no surprise that tree status, dbh and height are the most frequently measured and recorded parameters in the European NFIs as they are the most important ones for timber volume and growing stock estimations. In relation to possible harmonisation, $79 \%$ of the countries record some other stem damage attributes in their NFIs. This along with quantitative parameters might be useful for developing harmonised stem quality classification.

From the literature review and international standards, the most important parameters related to and necessary for generating a stem quality classification and assortments are identified (Table 5).

However, the study highlighted the great variability that exists in stem quality assessment and assessment of wood quality-related parameters among European NFIs. For 
Table 1 Stem parameters recorded during field measurement

\begin{tabular}{ll} 
Level of parameter assessment & No. Countries \\
\hline $\begin{array}{l}\text { Stem parameters related to stem } \\
\text { quality assessed in the field }\end{array}$ & 28 \\
Stem quality assessment & 18 \\
$\begin{array}{l}\text { Visually assessed quality classes } \\
\text { used to generate assortments }\end{array}$ & 8 \\
\hline
\end{tabular}

example in Sweden, parameters such as crown length, various damages, diameter of thickest branch (only on spruce and pine), presence and size of long-bend and/or abrupt bend are assessed and recorded. In addition core samples are taken to measure ring width and assess the presence of rot. However, they do not use these parameters to generate assortments of standing trees. In comparison the Netherlands assess wood quality of standing trees on trees with $\mathrm{dbh}>18 \mathrm{~cm}$ according to the criteria for saw logs (no stem damage, number of branches in the first $6 \mathrm{~m}$ of the stem height, and bends of less than $1 \mathrm{~cm} / \mathrm{m}$ in the first $6 \mathrm{~m}$ of the stem height). In Ireland, no direct stem quality assessment (using a classification system) is performed in NFI, but they measure or assess a range of timberquality-relevant parameters on standing trees (stem damage, forking, tree break, curvature, rottening, presence of fruiting body, branching, straightness, crown projection and upper diameter). They, however, plan to assess the possibility of implementing a stem quality classification in next NFI cycles. The Spanish NFI applies a special classification of stem quality. They use six categories based on health status and the possibility of the tree to provide quality goods: In the Belgian NFI, a direct stem quality assessment is used and each tree with dbh larger than $7 \mathrm{~cm}$ is assigned one of the four quality classes (A to D). These classes are similar to those used in Slovakia or Czech Republic. In Switzerland, they applied a comprehensive timber quality grading to four quality classes in their first NFI (1983-85) on a sub-sample of tally trees based on variables such as the branching or the curvature (on the lower $9 \mathrm{~m}$ of the tree height). The results were published in the final report (EAFV 1988). However, the assessment of variables was found not to be standardised between field teams. This led to dropping timber quality assessment from NFI. Based on this past experience, the Swiss NFI team have reconsidered this decision and are making efforts to re-integrate the stem quality into the NFI.

Overall, $79 \%$ of the NFIs measure and assess the most relevant parameters such as tree diameter and stem damage, which could be further used as a basis for the development of harmonised stem quality and assortment classification. In addition, growth rate as one of the other relevant parameters can be estimated from European NFIs.
Fig. 2 Distribution of countries which apply a timber quality classification system. Colour differentiated according to number of classes used in the NFI results

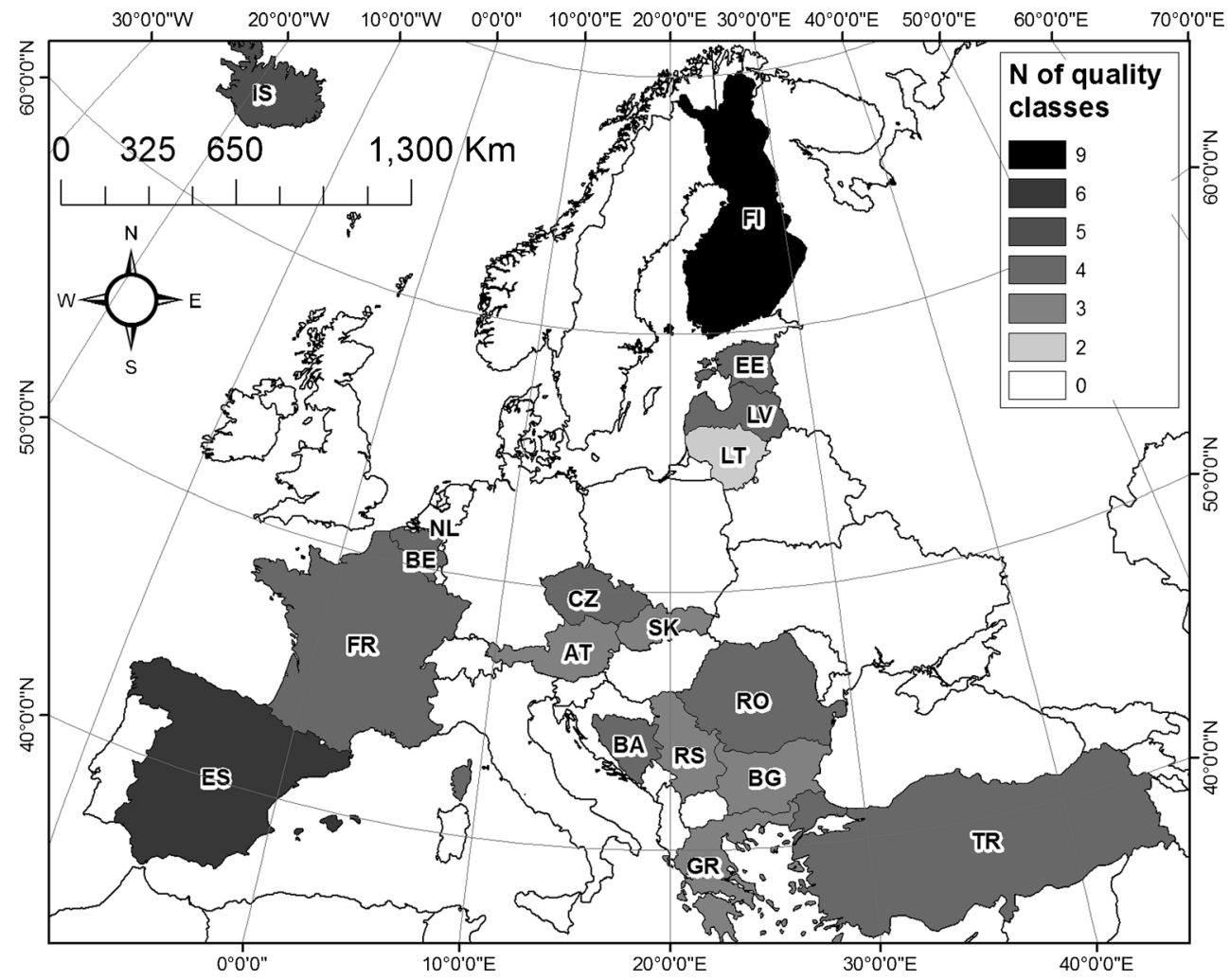


Fig. 3 Distribution of countries in which assortments are generated within their NFI

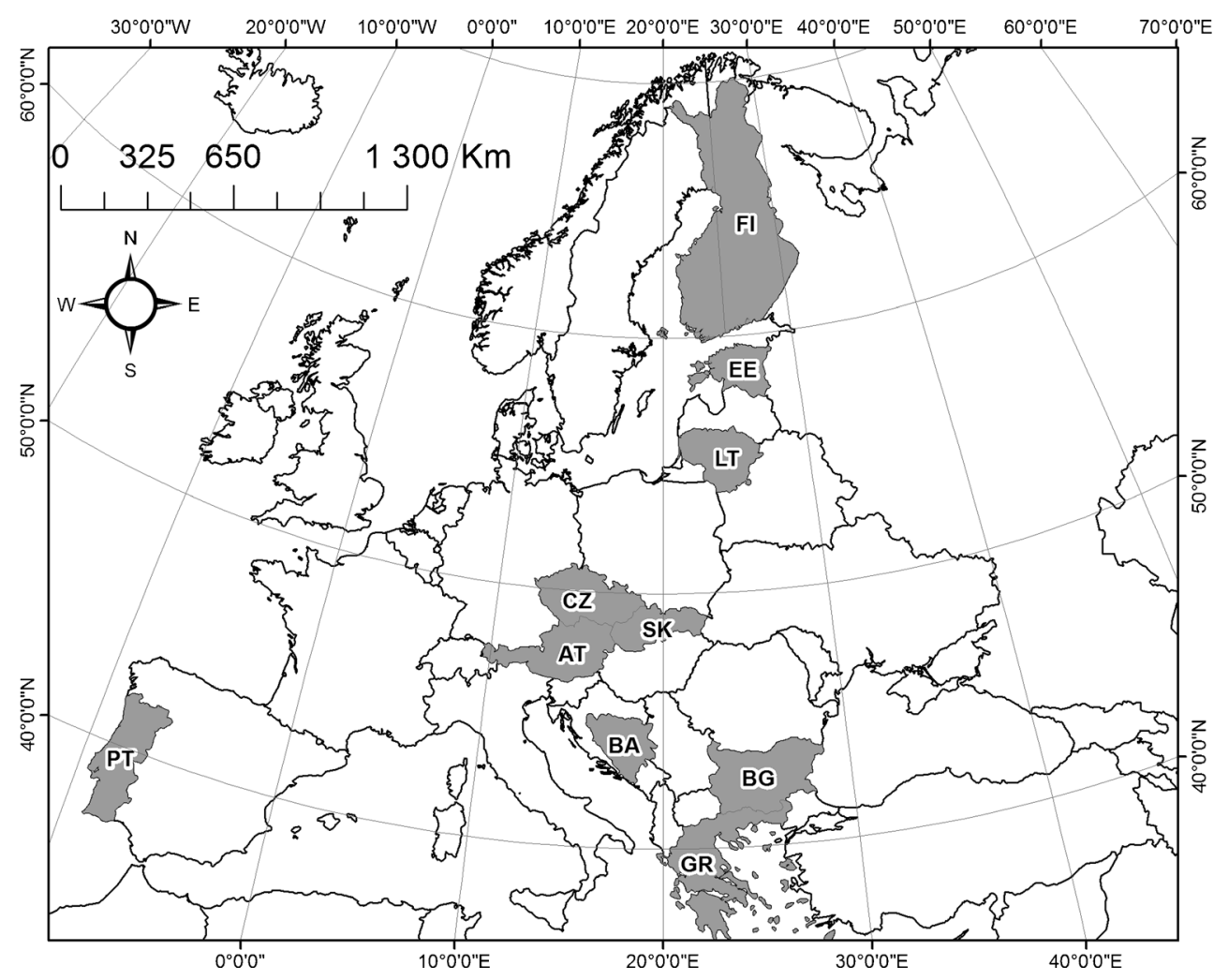

\section{Discussion}

The first step in the harmonisation process, before getting to harmonisation of timber-related parameters assessment and developing classification schemes for timber assortments estimations, is the harmonisation of thresholds and reference definitions for basic forest parameters such as forest/non-forest, other wooded land and other land categories, definition of growing stock, stem volume increment and its components. This process

Table 2 Sampling strategy to select trees in the plot for recording the parameters related to stem quality

\begin{tabular}{|c|c|c|}
\hline Level of sampling & No. countries & Percent $^{\mathrm{a}}$ \\
\hline All trees ${ }^{\mathrm{b}}$ & 11 & 39 \\
\hline Sub-sample & 15 & 54 \\
\hline \multicolumn{3}{|l|}{ Sampling parameter } \\
\hline Minimum dbh & 7 & 25 \\
\hline Minimum height & 1 & 4 \\
\hline Height sample trees only & 3 & 11 \\
\hline Species list & 2 & 7 \\
\hline Systematic & 1 & 4 \\
\hline Other & 2 & 7 \\
\hline
\end{tabular}

${ }^{\text {a }}$ Percentage calculated from all 28 countries

${ }^{\mathrm{b}}$ All trees recorded and measured in the plot (meeting the national threshold) was launched and intensive harmonisation efforts were made under the COST Action E43 (COST 2010) followed by the most recent COST Action FP1001 (COST 2015), where reference definitions were proposed and harmonisation possibilities developed (Vidal et al. 2008; Gschwantner et al. 2009; McRoberts et al. 2012; Ståhl et al. 2012; Tomppo and Schadauer 2012; Tomter et al. 2012). In general, all harmonisation efforts are based on bottom-up approach using existing inventory designs (Köhl et al. 2000) in order to maintain the original targets of NFIs and aim at developing methods to provide comparable estimates (McRoberts et al. 2009; 2010;

Table 3 Domain at which are attributes, which may be useful or are currently used for stem quality assessment, recorded in NFI

\begin{tabular}{lll}
\hline Assessment domain & No. countries & Percent $^{\mathrm{a}}$ \\
\hline Forest & 26 & 93 \\
OWL & 11 & 39 \\
ToF & 4 & 14 \\
FAWS & 7 & 25 \\
OLWTC & 0 & 0 \\
Other (productive forest) & 1 & 4
\end{tabular}

${ }^{\text {a }}$ Percentage calculated from all 28 countries

OWL Other Wooded Land; ToF Trees outside Forest; FAWS Forests Available for Wood Supply; OLWTC Other Land With Tree Cover 
Table 4 Number of countries that record standing tree quality parameters, which can be used to assess stem quality, in the field or use the parameters for stem quality assessment or for generating assortments

\begin{tabular}{|c|c|c|c|c|c|c|}
\hline \multirow[b]{2}{*}{ Parameter } & \multicolumn{2}{|c|}{ Recorded in the field } & \multicolumn{2}{|c|}{ Stem quality assessment } & \multicolumn{2}{|c|}{ Generation of assortments } \\
\hline & $N$ & $\%^{\mathrm{a}}$ & $N$ & $\%$ & $N$ & $\%^{\mathrm{c}}$ \\
\hline Tree status (dead, alive) & 28 & 100 & 17 & 94 & 10 & 91 \\
\hline Tree $d b h$ & 28 & 100 & 18 & 100 & 11 & 100 \\
\hline Tree height & 28 & 100 & 14 & 78 & 10 & 91 \\
\hline Stem damage & 22 & 79 & 16 & 89 & 8 & 73 \\
\hline Tree break & 21 & 75 & 15 & 83 & 8 & 73 \\
\hline Base of living crown & 19 & 68 & 10 & 56 & 5 & 45 \\
\hline Stem damage source & 18 & 64 & 13 & 72 & 5 & 45 \\
\hline Abiotic damage & 18 & 64 & 13 & 72 & 4 & 36 \\
\hline Forking & 18 & 64 & 13 & 72 & 7 & 64 \\
\hline Base of crown & 18 & 64 & 9 & 50 & 5 & 45 \\
\hline Biotic damage & 17 & 61 & 13 & 72 & 4 & 36 \\
\hline Splitting due to frost & 17 & 61 & 12 & 67 & 7 & 64 \\
\hline Rottening & 16 & 57 & 13 & 72 & 8 & 73 \\
\hline Splitting due to lightening & 14 & 50 & 12 & 67 & 7 & 64 \\
\hline Stem cavity & 13 & 46 & 11 & 61 & 6 & 55 \\
\hline Curvature & 12 & 43 & 12 & 67 & 8 & 73 \\
\hline Straightness & 12 & 43 & 12 & 67 & 8 & 73 \\
\hline Presence of fruiting body & 10 & 36 & 10 & 56 & 6 & 55 \\
\hline Branching & 10 & 36 & 10 & 56 & 5 & 45 \\
\hline Size of branches & 8 & 29 & 9 & 50 & 5 & 45 \\
\hline Artificial removal of branches & 8 & 29 & 4 & 22 & 1 & 9 \\
\hline Branching density & 7 & 25 & 11 & 61 & 5 & 45 \\
\hline Upper diameter & 7 & 25 & 4 & 22 & 6 & 55 \\
\hline Other & 6 & 21 & 6 & 33 & 4 & 36 \\
\hline Bark thickness & 5 & 18 & 4 & 22 & 4 & 36 \\
\hline Crown projection or diameter & 4 & 14 & 2 & 11 & 3 & 27 \\
\hline Staining of discolouration on bark & 3 & 11 & 6 & 33 & 2 & 18 \\
\hline Base of dead crown & 3 & 11 & 3 & 17 & 2 & 18 \\
\hline Stem taper & 3 & 11 & 6 & 33 & 4 & 36 \\
\hline Branch angle & 2 & 7 & 2 & 11 & 1 & 9 \\
\hline
\end{tabular}

a $\%$ of all countries involved in the study; ;

b $\%$ of 18 countries that have some kind of stem quality assessment

c $\%$ of countries that generate assortments in their NFI; italicised items of the first rows indicate the most important and most frequently assessed parameters which could be used for harmonised timber quality reporting

2012). Therefore, any other future harmonisation efforts should take the same approach.

\subsection{Timber quality-related parameters and their assessment in European NFIs}

There are many factors and standing tree quality parameters that can influence the timber properties in interaction with the conversion process and the relative size of the end products (sawn boards, peeled veneer, pulp and paper, among others, Table 5). However, it is possible to identify a less number of the most important ones. It has been reported that size, type and placement of knots (Duchesne et al. 1997), crown development (Mansfield et al. 2007; Lyhykäinen et al. 2009), branch size and placement (Mäkinen and Colin 1998), stem diameter, the ring width and cambial age (Houllier et al. 1995; Amarasekara and Denne 2002; Wilhelmsson et al. 2002) have an influence on wood fibre properties. However, wood fibre properties are not explicit in any timber grading rule. At the stand level, site productivity, stocking density, thinning type and intensity, competition and 
Table 5 List of factors and standing tree quality parameters measured in the field or derived from a model, which influence the timber properties and can thus be potentially used for timber assortment classification (the list was prepared from the review of European and national standards for timber grading)

\begin{tabular}{|c|c|c|c|c|}
\hline Type & Parameters & Field & Derived & Priority \\
\hline \multirow[t]{20}{*}{ Quantitative } & $\mathrm{dbh}$ & $\mathrm{X}$ & & 1 \\
\hline & Height & $\mathrm{X}$ & & 1 \\
\hline & Upper diameter & $\mathrm{X}$ & $\mathrm{X}$ & 2 \\
\hline & Bark thickness & $\mathrm{X}$ & $\mathrm{X}$ & 2 \\
\hline & Height to fork & $\mathrm{X}$ & & 2 \\
\hline & Live crown height & $\mathrm{X}$ & & 2 \\
\hline & Dead crown height & $\mathrm{X}$ & & 2 \\
\hline & Roundwood height & $\mathrm{X}$ & & 2 \\
\hline & Continual bole height & $\mathrm{X}$ & & 2 \\
\hline & Stem break height & $\mathrm{X}$ & & 2 \\
\hline & Branch number (living) & $\mathrm{X}$ & & 3 \\
\hline & Branch angle (living) & $\mathrm{X}$ & & 3 \\
\hline & Branch diameter (living) & $\mathrm{X}$ & & 3 \\
\hline & Branch number (dead) & $\mathrm{X}$ & & 3 \\
\hline & Branch angle (dead) & $\mathrm{X}$ & & 3 \\
\hline & Branch diameter (dead) & $\mathrm{X}$ & & 3 \\
\hline & Ovality or elipticity & $\mathrm{X}$ & & 2 \\
\hline & Sweep & $\mathrm{X}$ & & 3 \\
\hline & Taper & & $\mathrm{X}$ & 2 \\
\hline & Rate of growth (mm) & & $\mathrm{X}$ & 1 \\
\hline \multirow[t]{18}{*}{ Qualitative } & Species & $\mathrm{X}$ & & 1 \\
\hline & Tree status (dead/alive) & $\mathrm{X}$ & & 1 \\
\hline & Biotic stem damage & $\mathrm{X}$ & & 1 \\
\hline & Abiotic stem damage & $\mathrm{X}$ & & 1 \\
\hline & Frost/lightening stem damage & $\mathrm{X}$ & & 1 \\
\hline & Straightness & $\mathrm{X}$ & & 1 \\
\hline & Forking & $\mathrm{X}$ & & 2 \\
\hline & Break (stem, crown, top) & $\mathrm{X}$ & & 1 \\
\hline & Fluting & $\mathrm{X}$ & & 2 \\
\hline & Ovality & $\mathrm{X}$ & & 2 \\
\hline & Rottening & $\mathrm{X}$ & & 1 \\
\hline & Branch status (dead/alive) & $\mathrm{X}$ & & 2 \\
\hline & Branch size (low, med, high) & $\mathrm{X}$ & $\mathrm{X}$ & 2 \\
\hline & Artificial pruning & $\mathrm{X}$ & & 3 \\
\hline & Formative shaping & $\mathrm{X}$ & & 3 \\
\hline & Insect in timber (beetle, larvae holes) & $\mathrm{X}$ & & $1-2$ \\
\hline & Spiral grain & $\mathrm{X}$ & & 1 \\
\hline & Reaction wood & $X$ & & 2 \\
\hline
\end{tabular}

disturbance are important parameters indirectly determining timber quality (Houllier et al. 1995; Moore et al. 2009; Štefančík and Bošel'a 2014). As other indirect factors, climate condition and soil properties (besides influencing site productivity) play a role, primarily influencing wood specific gravity and wood stiffness (Moore et al. 2009; Filipescu et al. 2014). Climate dynamics determine the latewood proportion and thus the wood density (Lars et al. 2005). Site productivity effects tree growth rate and thus influences the wood density and stiffness (Moore et al. 2009). Also the position of trees on a slope may impact on wood stiffness, where trees growing on the ridge of a hill were more exposed to wind pressure which may cause trees to contain more stiff wood (Telewski 1989) than that growing in more sheltered sites.

The questionnaire shows that very few NFIs assess a number of timber quality parameters listed in Table 5 that could be used for developing harmonised timber quality classification. Less than $50 \%$ of NFIs assess parameters such as stem cavity, 
curvature, straightness, branching, branch angle or upper diameter. On the other hand, almost $80 \%$ of NFIs assess occurrence of stem damage and more than $60 \%$ even recognise sources of damage (abiotic, biotic, forking, etc.), which is very promising base for future harmonisation. Usually, stem quality-related parameters are assessed on all sample trees registered in the plot using different national thresholds for dbh ranging from 0 to $12 \mathrm{~cm}$ (Tomter et al. 2012). The NFIs that apply direct stem quality assessment in the field often apply different dbh thresholds (larger dbh) than that used for sample trees selection. For example, Austria uses dbh threshold of $20.5 \mathrm{~cm}$ for stem quality assessment, but $5 \mathrm{~cm}$ for sample tree selection to assess common tree parameters such as height, dbh and other.

\subsection{Direct assortments estimation on standing trees in NFIs}

Only few NFIs estimate the type of assortments present and the approaches employed differ considerably in the methodology (see example of European NFIs in Online Resource 3). Timber grading can be explained as a process during which a tree's stem is split into several classes as a combination of stem quality and tree dimension (e.g. dbh and height). However, this task is difficult for standing trees and it requires the visual assessment of timber quality directly in the field or measurement of important parameters related to timber quality. Several methods have been provided for grading single standing trees (Petráš and Nociar 1990, 1991a, b; Mecko et al. 1993; Petráš and Mecko 1995; Eckmüllner et al. 2007; Rais and Van De Kuilen 2012; Rais et al. 2014) or forest stands (Mecko et al. 1994a, b; Petráš et al. 2008). Generally, all methods include the development of taper functions and the translation of the stem volume into merchantable assortments. However, the number of parameters required for translating into the assortments differs between countries and studies and it depends on the grading system used in the timber market of the country. Although there are standards at European level, many country-level models for timber assortments of standing trees were developed in the past decades. For example, a large sample size consisting of more than 16000 felled trees including species such as Norway spruce, silver fir, Scots pine, oak species, European beech, hornbeam, birch, and European larch was used for development of tree-level regression models for converting stem volume into assortments proportions in Slovakia in 1990s (Petráš and Nociar 1991a, b; Mecko et al. 1993; see Online Resource 3 for more details). In Austria, taper functions and models for timber volume translation into the merchantable assortments have recently been developed reflecting the new grading standards in Austria (Eckmüllner et al. 2007).

\subsection{Towards harmonisation}

Köhl et al. (2000) recognises differences between harmonisation and standardisation. Harmonisation is defined as "to make or become harmonious or suitable, accommodate, adapt or agree" whilst he considers the standardisation as "to make to or regulate by a standard." Hence, harmonisation only requires a final conversion of estimates from the national to reference definition (Vidal et al. 2008). As all the past efforts focused on harmonisation of European NFIs rather than standardisation, it is desirable to keep the same approach for stem quality estimation. There are two possible approaches towards harmonisation: harmonisation of stem quality estimation and harmonisation of assortments estimation.

\subsubsection{Harmonisation of stem quality estimation}

If stem quality classification is the aim, the harmonisation would include the development of a harmonised stem quality estimation based on existing parameters assessed by most of the European NFIs.

Firstly, the development of harmonised definitions for selected tree parameters which are related to and are most important for stem quality is crucial. This includes mainly the harmonisation of thresholds for sample trees selection among NFIs and developing reference definitions (dbh, a part of stem to be assessed, intensity and type of stem damage, etc.).

To develop a harmonised stem quality estimation process, tree size and stem damage should be considered. It should also be recognised whether the stem damage is new or occurred several years ago as it highly affects the probability of rotting (the older the damage the higher the probability of heartwood rot) and thus decreases the timber quality (Petráš and Nociar 1990, 1991a; Vasiliauskas 2001). However, there are tree characteristics such as stem straightness, twisting, branching and other parameters which influence the timber quality and consequently its end use in the timber market. But such characteristics are usually not assessed in the NFIs. Therefore, additional site or stand parameters, which have a potential effect on the parameters, should be considered. For example, site quality (productivity) as a result of climate and soil conditions certainly has impacts on the stem quality (Wilhelmsson et al. 2002; Watt et al. 2006; Moore et al. 2009). Trees growing on poor productivity sites (very steep slopes, shallow soils, dry sites, etc.) usually have low quality stems. Hence, the site index might be included as another parameter to the classification. Although site index definition might differ between countries (mean tree height of $10 \%$, $20 \%, 30 \%$ or $100,200,300$ trees per hectare or even the mean height of dominant tree at the standard age of 50 or 100 years depending on species and region) a common definition should be adopted. In this sense, a conversion of the absolute site index to a relative scale (e.g. pure, good, very 
good) might be a good approach. The relation with site quality might, however, not be linear as trees growing on highly productive sites have high growth rates and thus thicker annual rings.

In addition, stand density might also be used as indirect indicator of timber properties (Moore et al. 2009). The higher density management leads to the smaller branch size, the higher intensity of debranching as well as the lower growth rate - all the properties that influence the final timber quality. Stocking density and thinning type ve also have a significant impact on production of high-quality beech stems Štefančík and Bošel'a (2014), so including them might improve stem quality and assortment classification. Also tree age was found to be an important factor in the occurrence of heartwood in beech (Petráš and Nociar 1991a, b; Knoke 2003), but this parameter is very difficult to assess and many NFIs use a combination several approaches with visual assessment being most frequent.

Many of the parameters related to stem quality assessment are based solely on visual assessment and classification by field teams. As proved by the past experiences of the Swiss NFI this may lead to biased estimate due to less reproducibility of some parameters. The potential to overcome this shortcoming in future lies in developing airborne laser scanning (ALS) techniques to assess stem quality-related parameters in a harmonised manner. Recent attempts showed quite promising results (Maltamo et al. 2009), but there is still a big challenge to employ these techniques on a large scale (national or regional). There is also a potential to employ terrestrial laser scanning (Kretschmer et al. 2013), but this is less efficient and less feasible to employ within NFI compared to ALS.

\subsubsection{Harmonisation of assortment estimation}

In the case of harmonisation of assortment estimation, a different approach should be applied. Assortments are the final product of the forest and the assessment of their proportion on the standing tree is a difficult and challenging task. Considering the current state of European NFIs, a possible option for harmonisation is using a model developed in a country with similar ecological conditions and with similar forest management and its adoption to the country of interest (neighbouring country).

In Europe, several national models for grading standing trees into assortments have been developed usually taking into account national-specific timber quality grading standards.

In some countries such models have been applied (Slovakia, Czech Republic, Romania and Austria) by NFI's to quantify assortment structure at national level (for example Šmelko et al. 2008). Other NFIs use some kind of visual assessment to quantify assortment proportions for trees in the inventory plot (Finland, Estonia, Portugal, Bulgaria,
Bosnia and Herzegovina, and Greece). In the Lithuanian NFI, two stem quality classes are assessed and wood structure models (Petrauskas et al. 2010) are used to estimate assortment structure of forests by main industrial assortments as well as firewood from both standing trees and felling residues such as logging losses, branches, and dead trees. The results from NFI are then used for controlling rationality of logging in the country and at ownership level (Online Resource 2).

In recent years, several different kinds of models estimating stem and wood properties have been developed (e.g. Kellomäki et al. 1999; Wilhelmsson et al. 2002; Ikonen et al. 2003; Repola 2006; Kantola et al. 2007; Mäkinen et al. 2007; Molteberg and Hoibo 2007), which may be useful for harmonisation.

Although many kinds of empirical or process-based models have been developed in Europe to estimate assortments, these models only provide modelled results and the reality may thus be far from the prediction. Estimating assortments on standing trees seems not to be the best approach towards harmonisation and simpler stem quality assessment should thus be preferred. In addition, as only eight NFIs apply a timber assortments classification and provide national statistics for assortment proportions (e.g. Šmelko et al. 2008), this is probably not the way to go towards harmonisation between NFIs at the moment. Any efforts to harmonise assortments estimations would be costly and inefficient unless ALS and/ or terrestrial laser scanning (TLS) techniques would have been developed to be feasible for large scale forest inventories (Maltamo et al. 2009; Kankare et al. 2014a,b; van Leeuwen et al. 2011).

\section{Conclusions}

The study showed large differences in stem quality assessment among European NFIs. Furthermore, very few countries go beyond the stem quality assessment to estimate timber assortments either by direct assessment in the field or by further application of a model developed in the country.

The inquiry showed that the current systems are not capable of reporting the stem quality of European forests in a harmonised manner at this stage. However, the quantity alone will not be sufficient to satisfy policy needs and progressively steps should be taken to harmonise stem quality estimations. Considerable efforts will be required before the harmonised stem quality assessment or assortments estimation can be prepared.

As pointed out by Tomppo and Schadauer (2012), standardisation is not feasible at European level in a near future and harmonisation should be considered instead. Harmonisation processes for stem quality estimation in immediate future will need to consider the following steps: (a) selection of main timber quality-related parameters and 
development of reference definitions for both the common quality-related parameters and registration thresholds; (b) development of bridging functions for countries that do not assess some of the selected parameters; and (c) testing feasibility of developed harmonised stem quality estimates. Such approach was already tested and the results proved it is a feasible way towards harmonisation (Vidal et al. 2008; Tomter et al. 2012; Ståhl et al. 2012).

In Europe, the laser scanning techniques, both airborne and terrestrial, have developed very quickly. This technology may thus play a vital role in future to develop a harmonised timber quality assessment on standing trees also within NFIs.

Acknowledgments We warmly thank all participants involved in the COST Action FP1001 and especially those who contributed to the study and provided us with answers and country reports. We also thank the three anonymous reviewers for their relevant comments and suggestions. The study was supported by the European Union through COST Action FP 1001 "Improving Data and Information on the Potential Supply of Wood Resources: A European Approach from Multisource National Forest Inventories (USEWOOD)." Michal Bosela was also supported by the Slovak Research and Development Agency under the project APVV0262-11.

\section{References}

Amarasekara H, Denne MP (2002) Effects of crown size on wood characteristics of Corsican pine in relation to definition of juvenile wood, crown formed wood and core wood. Forestry 75:51-61. doi:10. 1093/forestry/75.1.51

Chauhan S, Donnelly R, Huang C-L, Nakada R, Yafang Y, Walker J (2006) Wood quality: in context. In: Walker J (ed) Primary wood processing: principles and practice, 2 nd edn. Springer, Dordrecht, $p p$ $121-158$

COST (2010) Action E43: Harmonisation of National Forest Inventories in Europe: Techniques for common reporting. www.metla.fi/eu/cost/ e43. Accessed on 19 Mar 2015

COST (2015) Action FP1001: Improving Data and Information on the Potential Supply of Wood Resources: A European Approach from Multisource National Forest Inventories (USEWOOD). https://sites. google.com/site/costactionfp1001/. Accessed 19 Mar 2015

Directive 98/34/EC A procedure for the provision of information in the field of technical standards and regulations and rules on Information Society services"

Duchesne I, Wilhelmsson L, Spangberg K (1997) Effects of in-forest sorting of Norway spruce (Picea abies) and Scots pine (Pinus sylvestris) on wood and fibre properties. Can J For Res 27:790 795. doi:10.1139/x97-040

Eckmüllner O, Schedl P, Sterba H (2007) Neue Schaftkurven für die Hauptbaumarten Österreichs und deren Ausformung in marktkonforme Sortimente [New taper curves for the main tree species in Austria and their merchantable assortment]. Aust J For Sci 124:215-236

Eidg. Anstalt für das forstliche Versuchswesen (EAFV) Budesamt für Forstwesen und Landschaftsschutz (BFL) (1988) Schweizerisches Landesforstinventar. Ergebnisse der Erstaufnahme 1982-1986. Eidg Anst forstl Versuchswes, Bericht Nr 305, 375 p

Eriksson E, Gillespie AR, Gustavsson L, Langvall O, Olsson M, Sathre R, Stendahl J (2007) Integrated carbon analysis of forest management practices and wood substitution. Can J For Res 37: 671-681. doi:10.1139/X06-257

European Parliament and Council of the European Union (2009) Directive 2009/28/EC on the promotion of the use of energy from renewable sources

FAO (2010) Global Forest Resources Assessment 2010, FAO, Food and Agriculture Organization of the United Nations, Rome (URL: http:// www.fao.org/forestry/fra/fra2010/en/)

Filipescu CN, Lowell EC, Koppenaal R, Mitchell AK (2014) Modeling regional and climatic variation of wood density and ring width in intensively managed Douglas-fir. Can J For Res 44:220-229. doi: 10.1139/cjfr-2013-0275

Gschwantner T, Schadauer K, Vidal C, Lanz A, Tomppo E, di Cosmo L, Robert N, Englert Duursma D, Lawrence M (2009) Common tree definitions for national forest inventories in Europe. Silva Fenn 43: 303-321

Houllier F, Leban JM, Colin F (1995) Linking growth modelling to timber quality assessment for Norway spruce. For Ecol Manag 74:91102. doi:10.1016/0378-1127(94)03510-4

Ikonen V-P, Kellomäki S, Peltola H (2003) Linking tree stem properties of Scots pine to sawn timber properties through simulated sawing. For Ecol Manag 174:251-263

IPCC (2014) 2013 Revised Supplementary Methods and Good Practice Guidance Arising from the Kyoto Protocol. Hiraishi T, Krug T, Tanabe K, Srivastava N, Baasansuren J, Fukuda M, Troxler TG (eds) Published: IPCC, Switzerland

Kankare V, Vauhkonen J, Tanhuanpää T, Holopainen M, Vastaranta M, Joensuu M, Krooks A, Hyyppä J, Hyyppä H, Alho P, Viitala R (2014a) Accuracy in estimation of timber assortments and stem distribution - a comparison of airborne and terrestrial laser scanning techniques. Int Soc Photogr 97:89-97. doi:10.1016/j.isprsjprs.2014. 08.008

Kankare V, Joensuu M, Vauhkonen J, Holopainen M, Tanhuanpää T, Vastaranta M, Hyyppä J, Hyyppä H, Alho P, Rikala J, Sipi M (2014b) Estimation of the timber quality of scots pine with terrestrial laser scanning. Forests 5:1879-1895. doi:10.3390/ f5081879

Kantola A, Mäkinen H, Mäkelä A (2007) Stem form and branchiness of Norway spruce as a sawn timber - predicted by a process based model. For Ecol Manag 241:209-222. doi:10.1016/j.foreco.2007. 01.013

Kellomäki S, Ikonen V-P, Peltola H, Kolström T (1999) Modelling the structural growth of Scots pine with implications for wood quality. Ecol Model 122:117-134. doi:10.1016/S03043800(99)00086-1

Kliger IR, Johansson G, Perstorpher M, Engström D (1994) Formulation of requirements for the quality of wood properties used by the construction industry. Final report EC contract No. MA2B-0024. Chalmers University of Technology, Sweden

Knoke T (2003) Predicting red heartwood formation in beech trees (Fagus sylvatica L.). Ecol Model 169:295-312. doi:10.1016/ S0304-3800(03)00276-X

Köhl M, Traub B, Päivinen R (2000) Harmonisation and standardisation in multi-national environmental statistics - mission impossible? Environ Monit Assess 63:361-380. doi:10. 1023/A:1006257630216

Kretschmer U, Kirchner N, Morhart C, Spiecker H (2013) A new approach to assessing tree stem quality characteristics using terrestrial laser scans. Silva Fenn 47:1-14. doi:10.14214/sf.1071

Lars K, Mörling T, Owe M (2005) Wood density, annual ring width and latewood content in Larch and Scots pine. Eur J For Res 8 2:91-96

Lyhykäinen HT, Mäkinen H, Mäkelä A, Pastila S, Heikkilä A, Usenius A (2009) Predicting lumber grade and by-product 
yields for Scots pine trees. For Ecol Manag 258:146-158. doi: 10.1016/j.foreco.2009.03.054

MacDonald E, Hubert J (2002) A review of the effects of silviculture on timber quality of Sitka spruce. Forestry 75:107-138. doi:10.1093/ forestry/75.2.107

Mäkinen H, Colin F (1998) Predicting branch angle and branch diameter of Scots pine from usual tree measurements and stand structural information. Can J For Res 28:1686-1696. doi:10. 1139/x98-141

Mäkinen H, Jaakkola T, Piispanen R, Saranpää P (2007) Predicting wood and tracheid properties of Norway spruce. For Ecol Manag 241: 175-188. doi:10.1016/j.foreco.2007.01.017

Maltamo M, Peuhkurinen J, Malinen J, Vauhkonen J, Packalén P, Tokola T (2009) Predicting tree attributes and quality characteristics of Scots pine using airborne laser scanning data. Silva Fenn 43:507521. doi:10.14214/sf.203

Mansfield SD, Parish R, Goudie JW, Kang K, Ott P (2007) The effects of crown ratio on the transition from juvenile to mature wood production in lodgepole pine in western Canada. Can J For Res 37:1450 1459. doi:10.1139/X06-299

McRoberts RE, Tomppo E, Schadauer K, Vidal C, Ståhl G, Chirici G, Lanz A, Cienciala E, Winter S, Smith WB (2009) Harmonizing National Forest Inventories. J For 107:179-187

McRoberts RE, Ståhl G, Vidal C, Lawrence M, Tomppo E, Schadauer K, Chirici G, Bastrup-Birk A (2010) National Forest Inventories: Prospects for harmonised international reporting. In: Tomppo E, Gschwantner T, Lawrence M, McRoberts RE (eds) National Forest Inventories - Pathways for Common Reporting, pp 33-43

McRoberts R, Tomppo EO, Schadauer K, Stahl G (2012) Harmonizing National Forest Inventories. For Sci 58(3):189-190

Mecko J, Petráš R, Nociar V (1993) Konštrukcia nových stromových sortimentačných tabuliek pre smrekovec, hrab a brezu [Construction of new tree-level assortment models for European larch, hornbeam and birch species]. Lesnícky časopis 39:2096-2221

Mecko J, Petráš R, Nociar V (1994a) Konštrukcia nových porastových sortimentačných tabuliek pre smrekovec, hrab a brezu [Construction of new stand-level assortment models for European larch, hornbeam and birch species]. Lesnícky časopis 40:115-124

Mecko J, Petráš R, Nociar V (1994b) Sortimentačné tabul'ky pre smrekovec, hrab a brezu [Assortment tables for European larch, hornbeam and birch species]. Bratislava, Veda, $76 \mathrm{pp}$

Mitchell HL (1961) A concept of intrinsic wood quality, and non-destructive methods for determining quality in standing timber. Report No. 2233. Forest Products Laboratory, Madison

Molteberg D, Hoibo O (2007) Modelling of wood density and fibre dimensions in mature Norway spruce. Can J For Res 37:13731389. doi:10.1139/X06-296

Moore JR, Lyon AJ, Searles GJ, Vihermaa LE (2009) The effects of site and stand factors on the tree and wood quality of sitka spruce growing in the United Kingdom. Silva Fenn 43:383396

Nuutinen T, Kilpeläinen A, Hirvelä H, Härkönen K, Ikonen V-P, Lempinen R, Peltola H, Wilhelmsson L, Kellomäki S (2009) Future wood and fibre sources - case North Karelia in eastern Finland. Silva Fenn 43:489-505

Petráš R, Mecko J (1995) Models of volume, quality and value production of tree species in the Slovak Republic. Lesníctví-Forestry 41: 194-196

Petráš R, Nociar V (1990) Nové sortimentačné tabul'ky hlavných listnatých drevín [New assortment models for main broadleaved species in Slovakia]. Lesnícky časopis 36:535-552
Petráš R, Nociar V (1991a) Nové sortimentačné tabul'ky hlavných ihličnatých drevín [New assortment models for main coniferous species in Slovakia]. Lesnícky časopis 37:377-392

Petráš R, Nociar V (1991b) Sortimentačné tabul'ky hlavných drevín [Assortment tables of main tree species in Slovakia]. Bratislava, Veda, $304 \mathrm{pp}$

Petráš R, Mecko J, Nociar V (2008) Models of assortment yield tables for poplar clones. J For Sci 54:227-233

Petrauskas E, Kuliešis A, Tebèra A (2010) Medienos tūrio lentelès. Ketvirtoji papildyta ir pataisyta laida [Wood volume tables (Fourth revised edition)]. Naujasis Lankas, Kaunas, $192 \mathrm{p}$

Rais A, Van De Kuilen J-WG (2012) Pre-grading of douglas-fir logs for glulam lamella production. World Conference on Timber Engineering 2012, WCTE 2010 1:300-304

Rais A, Pretzsch H, Van De Kuilen J-WG (2014) Roundwood pregrading with longitudinal acoustic waves for production of structural boards. Eur J Wood Wood Prod 72:87-98. doi:10.1007/s00107013-0757-5

Repola J (2006) Models for vertical wood density of Scots pine, Norway spruce and birch stems, and their application to determine average wood density. Silva Fenn 40:673-685

Schneider R, Riopel M, Pothier D, Côté L (2008) Predicting decay and round-wood end use volume in trembling aspen (Populus tremuloides Michx.). Ann For Sci 65:608. doi:10.1051/ forest:2008042

Šmelko Š, Šebeň V, Bošel'a M, Merganič J, Jankovič J (2008) National Forest Inventory and Monitoring of the Slovak Republic 2005-2006. Basic concept and selected summary informations. National Forest Centre - Forest Research Institute Zvolen, $16 \mathrm{pp}$

Ståhl G, Cienciala E, Chirici G, Lanz A, Vidal C, Winter S, McRoberts RE, Rondeux J, Schadauer K, Tomppo E (2012) Bridging national and reference definitions for harmonizing forest statistics. For Sci 58:214-223

Štefančík I, Bošel'a M (2014) An influence of different thinning methods on qualitative wood production of European beech (Fagus sylvatica L.) on two eutrophic sites in the Western Carpathians. J For Sci 60: 406-416

Telewski FW (1989) Structure and function of flexure wood of Abies fraseri. Tree Physiol 5:113-121

Tomppo E, Schadauer K (2012) Harmonization of National Forest Inventories in Europe: Advances under COST Action E43. For Sci 58:191-200

Tomppo E, Gschwantner T, Lawrence M, McRoberts RE (Eds.) (2010) National Forest Inventories: Pathways for Common Reporting. Springer Science+Business Media B.V, doi: 10.1007/978-90-4813233-1 1

Tomter S, Gasparini P, Gschwantner T, Hennig P, Kulbokas G, Kuliešis A, Polley H, Robert N, Rondeux J, Tabacchi G, Tomppo E (2012) Establishing bridging functions for harmonizing growing stock estimates: examples from European National Forest Inventories. For Sci 58:224-235

van Leeuwen M, Hilker T, Coops NC, Frazer G, Wulder MA, Newnham GJ, Culvenor DS (2011) Assessment of standing wood and fiber quality using ground and airborne laser scanning: a review. For Ecol Manag 261:1467-1478. doi:10.1016/j. foreco.2011.01.032

Vasiliauskas R (2001) Damage to trees due to forestry operations and its pathological significance in temperate forests: a literature review. Forestry 74:319-336. doi:10.1093/forestry/74.4.319

Vidal C, Lanz A, Tomppo E, Schadauer K, Gschwantner T, di Cosmo L, Robert N (2008) Establishing forest inventory reference definitions for forest and growing stock: a study towards common reporting. Silva Fenn 42:247-266 
Watt MS, Moore JR, Facon J, Downes J, Clinton PM, Coker G, Davis MR, Simcock R, Parfitt RL, Dando J, Mason EG, Bown HE (2006) Modelling the influence of stand structural, edaphic and climatic influences on juvenile Pinus radiate dynamic modulus of elasticity. For Ecol Manag 229:136-144. doi:10.1016/j.foreco.2006.03.016

Wikström P, Edenius L, Elfving B, Eriksson LO, Lämås T, Sonesson J, Öhman K, Wallerman J, Waller C, Klintebäck F (2011) The Heureka forestry decision support system: an overview. Math Comput For Nat Res Sci 3:87-94
Wilhelmsson L, Arlinger J, Spangberg K, Lundqvist S-O, Grahn T, Hedenberg O, Olsson L (2002) Models for predicting wood properties in stems of Picea abies and Pinus sylvestris in Sweden. Scand J For Res 17:330-350. doi:10.1080/ 02827580260138080

Zhang SY (1997) Wood quality: its definition, impact and implications for value-added timber management and end use. In: Zhang SY, Gosselin R, Chauret G (eds) Proceedings of the CTIA/IUFRO International Wood Quality Workshop. Quebec City, Part I, pp 17-39 